\title{
A comparative study of the enzymatic hydrolysis of batch organosolv-pretreated birch and spruce biomass
}

\author{
Vijayendran Raghavendran ${ }^{1,3}$, Christos Nitsos², Leonidas Matsakas², Ulrika Rova², Paul Christakopoulos ${ }^{2}$ \\ and Lisbeth Olsson ${ }^{1 *}$ (B)
}

\begin{abstract}
A shift towards a sustainable and green society is vital to reduce the negative effects of climate change associated with increased $\mathrm{CO}_{2}$ emissions. Lignocellulosic biomass is both renewable and abundant, but is recalcitrant to deconstruction. Among the methods of pretreatment available, organosolv (OS) delignifies cellulose efficiently, significantly improving its digestibility by enzymes. We have assessed the hydrolysability of the cellulose-rich solid fractions from OS-pretreated spruce and birch at $2 \% \mathrm{w} / \mathrm{v}$ loading (dry matter). Almost complete saccharification of birch was possible with $80 \mathrm{mg}$ enzyme preparation $/ \mathrm{g}_{\text {solids }}\left(12 \mathrm{FPU} / \mathrm{g}_{\text {solids }}\right)$, while the saccharification yield for spruce was only $70 \%$, even when applying $60 \mathrm{FPU} / \mathrm{g}_{\text {solids. }}$. As the cellulose content is enriched by OS, the yield of glucose was higher than in their steam-exploded counterparts. The hydrolysate was a transparent liquid due to the absence of phenolics and was also free from inhibitors. OS pretreatment holds potential for use in a large-scale, closed-loop biorefinery producing fuels from the cellulose fraction and platform chemicals from the hemicellulose and lignin fractions respectively.
\end{abstract}

Keywords: Cellic CTec2, Cellulose-rich biomass, Delignification, Inhibitor-free biomass, Saccharification yield

\section{Introduction}

There is an urgent need to produce fuels and chemicals from renewable resources, and drastic actions are required to combat the emissions of greenhouse gases, as underlined in the report by the Intergovernmental Panel on Climate Change (Houghton 2009; IPCC 2014). The increase in population and the transition to an urban lifestyle, with its concomitant dependency on technology and increase in economic growth, will place/is already placing enormous pressure on the global demand for energy (Smil 2004) and food (The World Bank 2014). The chemical industry contributes about 5.2 trillion USD per annum to the global economy, and the transition to bio-based processes is imperative if we are to reduce

\footnotetext{
*Correspondence: lisbeth.olsson@chalmers.se

${ }^{1}$ Industrial Biotechnology Division, Department of Biology and Biological Engineering, Chalmers University of Technology, Kemivägen 10, 412

96 Gothenburg, Sweden

Full list of author information is available at the end of the article
}

our dependence on petrochemical feedstocks (Tan et al. 2016; Robertson et al. 2017; Lange 2017).

Biomass is an abundant renewable feedstock (Perlack and Stokes (Leads) 2011; Limayem and Ricke 2012; Kluts et al. 2017). However, it requires pretreatment (McCann and Carpita 2015) to release sugars that can be utilized by microorganisms to produce the products of interest. Several pretreatment methods, such as acid/alkaline hydrolysis, dilute ammonia, liquid hot water, sulfur dioxide, are available for biomass deconstruction (Mosier et al. 2005), but these processes produce compounds such as hydroxyl methyl furfural (HMF), furfural and acetic acid, which are inhibitory to the microorganisms used for fermentation (Piotrowski et al. 2014, 2015), or to the saccharification enzymes (Ximenes et al. 2011). Organosolv (OS) pretreatment-proposed as early as 1931 (Kleinert and v. Tayenthal 1931) for delignification (Johansson et al. 1987; Sannigrahi and Ragauskas 2013; Brosse et al. 2017), has gained much interest recently (Pan et al. 2005; Nguyen et al. 2015; Guragain et al. 2016; Katsimpouras 
et al. 2017a, b). OS pretreatment provides three distinct streams: a solids stream enriched in cellulose, thus offering better digestibility by cellulases; a hemicellulose stream containing xylose and xylans (that can be used by pentose-utilizing yeasts or chemically converted to platform chemicals such as HMF); and finally, a lignin stream offering valorization through chemical and thermal conversion, thereby providing added value to the process.

Nitsos and coworkers (2016) recently demonstrated the efficient dissolution of lignin combined with extensive hemicellulose removal for spruce and birch, using batch OS (with ethanol as the solvent and sulfuric acid as the catalyst). In the present study, we used these OSpretreated, cellulose-rich solid fractions to assess their hydrolysability using a commercial enzyme solution. We also carried out enzyme dosage studies on the OSisolated/pretreated cellulose fractions that performed best during hydrolysis, to compare the yields with their steam-pretreated counterparts.

\section{Materials and methods}

\section{Pretreatment}

Figure 1 shows a schematic of the batch OS pretreatment process used in our recently presented work on birch and spruce biomass fractionation (Nitsos et al. 2016). A total of 24 cellulose-enriched biomass samples were obtained by varying the concentration of the acid catalyst
(0 or $1 \mathrm{wt} \% \mathrm{H}_{2} \mathrm{SO}_{4}$ ), the duration of pretreatment ( 60 or $103 \mathrm{~min}$ ), the ethanol concentration (50 or $60 \mathrm{wt} \%$ ), and the particle size $(<1$ or $<4 \mathrm{~mm})$. Table 1 gives the conditions employed for biomass fractionation and the composition of the enriched biomass (Nitsos et al. 2016). Steam-exploded (SE) birch $\left(200{ }^{\circ} \mathrm{C}, 5 \mathrm{~min}\right.$ and $0.14 \mathrm{wt} \%$ $\left.\mathrm{H}_{2} \mathrm{SO}_{4}\right)$ and spruce $\left(225^{\circ} \mathrm{C}, 5 \mathrm{~min}\right.$ and $\left.0.5 \mathrm{wt} \% \mathrm{H}_{2} \mathrm{SO}_{4}\right)$ solids were used as controls.

\section{Enzymatic hydrolysis}

Hydrolysis of the 24 samples with a dry matter content of $2 \%(\mathrm{w} / \mathrm{v})$ was performed in cotton stoppered (and aluminum covered) $100 \mathrm{~mL}$ flasks, in a final volume of $40 \mathrm{~mL}$. Citrate buffer at $\mathrm{pH} 4.8$ and $50 \mathrm{mM}$ final concentration was used to maintain the $\mathrm{pH}$ during hydrolysis. A stock solution of Cellic CTec2 (provided by Novozymes, Bagsværd, Denmark) was prepared, and appropriate volumes of the enzyme solution were used according to the dosages given in Table 1. A low enzyme loading of $20 \mathrm{mg}$ enzyme preparation $/ \mathrm{g}_{\text {solids }}$ (corresponding to $3 \mathrm{FPU} / \mathrm{g}_{\text {solids }}$ ) and an incubation time of $48 \mathrm{~h}$ was used during the initial screening experiments. Subsequently, dosages of 40, 80, 150, 300 and $400 \mathrm{mg}$ enzyme preparation $/ \mathrm{g}_{\text {solids }}$ were investigated. This preparation has a specific activity of $150 \mathrm{FPU} / \mathrm{g}$ (Wang et al. 2014), and thus $1 \mathrm{mg}$ of enzyme preparation corresponds to $0.15 \mathrm{FPU}$. The flasks were incubated in a shaking water bath (OLS

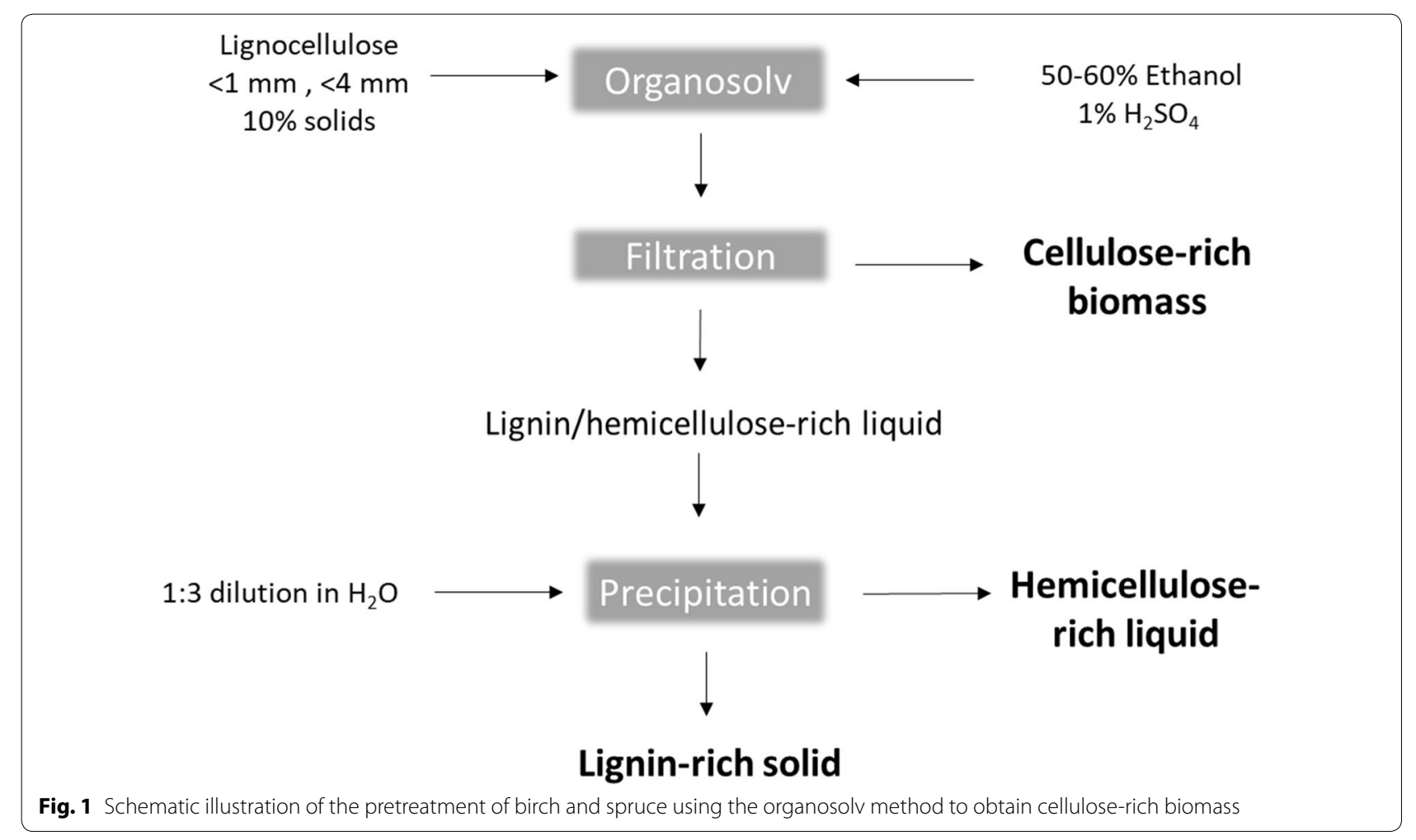


Table 1 The conditions used in organosolv (OS) and steam explosion (SE) pretreatment together with the composition of the biomass obtained. From Nitsos et al. (2016)

\begin{tabular}{|c|c|c|c|c|c|c|c|c|c|c|c|c|}
\hline \multirow{4}{*}{$\begin{array}{l}\text { Time } \\
\text { Particle size } \\
\mathrm{H}_{2} \mathrm{SO}_{4}(w / v)\end{array}$} & \multicolumn{8}{|c|}{ Biomass extracted with $50 \%(\mathrm{v} / \mathrm{v})$ ethanol } & \multirow{2}{*}{\multicolumn{4}{|c|}{$\begin{array}{l}\text { Biomass extracted with } 60 \%(\mathrm{v} / \mathrm{v}) \\
\text { ethanol } \\
60 \mathrm{~min}, 182^{\circ} \mathrm{C}\end{array}$}} \\
\hline & \multicolumn{4}{|c|}{$60 \mathrm{~min}, 182^{\circ} \mathrm{C}$} & \multicolumn{4}{|c|}{$103 \mathrm{~min}, 182^{\circ} \mathrm{C}$} & & & & \\
\hline & \multicolumn{2}{|c|}{$1 \mathrm{~mm}$} & \multicolumn{2}{|c|}{$4 \mathrm{~mm}$} & \multicolumn{2}{|c|}{$1 \mathrm{~mm}$} & \multicolumn{2}{|c|}{$4 \mathrm{~mm}$} & \multicolumn{2}{|c|}{$1 \mathrm{~mm}$} & \multicolumn{2}{|c|}{$4 \mathrm{~mm}$} \\
\hline & $0 \%$ & $1 \%$ & $0 \%$ & $1 \%$ & $0 \%$ & $1 \%$ & $0 \%$ & $1 \%$ & $0 \%$ & $1 \%$ & $0 \%$ & $1 \%$ \\
\hline \multicolumn{13}{|l|}{ Birch } \\
\hline Cellulose & 62.2 & 59.6 & 61.4 & 57.6 & 63.7 & 57.8 & 61.4 & 62.4 & 59.0 & 60.7 & 62.1 & 63.8 \\
\hline Hemicellulose & 3.0 & 0.5 & 4.6 & 0.3 & 2.6 & 0.4 & 2.7 & 0.2 & 3.3 & 1.1 & 4.3 & 1.1 \\
\hline Lignin & 16.0 & 24.1 & 14.6 & 21.8 & 17.5 & 25.9 & 15.8 & 23.7 & 16.8 & 15.7 & 13.8 & 16.0 \\
\hline Total (wt\%) & 81.2 & 84.1 & 80.6 & 79.8 & 83.8 & 84.2 & 79.9 & 86.3 & 79.0 & 77.5 & 80.2 & 80.9 \\
\hline \multicolumn{13}{|l|}{ Spruce } \\
\hline Cellulose & 52.5 & 56.1 & 53.8 & 58.0 & 54.5 & 55.9 & 56.1 & 55.2 & 50.3 & 69.1 & 49.1 & 67.3 \\
\hline Hemicellulose & 5.0 & 2.0 & 6.4 & 2.4 & 5.6 & 3.5 & 7.3 & 2.8 & 13.2 & 1.2 & 14.5 & 2.8 \\
\hline Lignin & 29.9 & 31.7 & 26.3 & 29.8 & 28.4 & 37.8 & 25.8 & 40.9 & 23.7 & 25.0 & 26.0 & 24.2 \\
\hline Total (wt\%) & 87.4 & 89.8 & 86.5 & 90.1 & 88.5 & 97.2 & 89.2 & 98.9 & 87.2 & 95.3 & 89.6 & 94.3 \\
\hline
\end{tabular}

Composition of untreated birch (by wt\%): $34.7 \%$ cellulose, $31.2 \%$ hemicellulose, and $18.7 \%$ lignin; composition of untreated spruce: $37.6 \%$ cellulose, $27.4 \%$ hemicellulose, and $32.6 \%$ lignin; composition of steam exploded birch: $57.2 \%$ cellulose, $12.1 \%$ hemicellulose, and $27.1 \%$ lignin (Matsakas et al. 2018); composition of steam exploded spruce: $38.2 \%$ cellulose, $53.1 \%$ lignin

200, Grant Instruments, Cambridge, UK), at $120 \mathrm{rpm}$ (using an orbital arm of $9 \mathrm{~mm}$ radius) for $48 \mathrm{~h}$ at $50{ }^{\circ} \mathrm{C}$. All experiments were performed in duplicate. The Analysis ToolPak in Microsoft Excel was used to determine the $\mathrm{p}$-values using the student's t test (two samples assuming equal variances, with a significance level of probability set at $\mathrm{p}<0.05)$.

\section{Analytical determination}

Samples obtained before and after hydrolysis (at 0 and $48 \mathrm{~h}$ ) were filtered through $0.2 \mu \mathrm{m}$ nylon syringe filters and stored at $-20{ }^{\circ} \mathrm{C}$ until further analysis. The glucose released was determined using HPLC at $80{ }^{\circ} \mathrm{C}$ with a Rezex column and a refractive index detector. The eluent was $5 \mathrm{mM} \mathrm{H}_{2} \mathrm{SO}_{4}$ and the flow rate $0.8 \mathrm{~mL} / \mathrm{min}$.

\section{Calculation of saccharification yield}

The saccharification yield is defined as:

$$
\eta=100 *\left(\frac{C_{\text {glucose }} * V_{\text {liquid }} * 0.90}{m_{\text {solids }} * x_{\text {cellulose }}}\right)
$$

where $C_{\text {glucose }}$ is the concentration of glucose obtained by HPLC, in $\mathrm{g} / \mathrm{L}, V_{\text {liquid }}$ is the volume of the liquid used in hydrolysis; 0.90 is the correction factor for the addition of a molecule of water during the hydrolytic reaction; $x_{\text {cellulose }}$ is the mass fraction of cellulose in the pretreated solids, and $m_{\text {solids }}$ is the mass of pretreated solids in the experiment. All the masses used in the calculations were on a dry basis.

\section{Results}

Enzymatic hydrolysis of OS pretreated birch and spruce biomass

Nitsos and co-workers (2016) did an extensive characterization of batch OS treated birch and spruce biomass including the hemicellulose and lignin fraction. Here we screened the pretreated biomass from such a process for their hydrolysability aiming to study their potential for further use in microbial conversion processes. The saccharification yield of OS pretreated birch and spruce are shown in Fig. 2. No statistically significant differences were found between samples of the same wood type with and without the acid catalyst, or between various particle sizes, or ethanol concentration, although the use of the acid catalyst led to somewhat higher saccharification yields. However, differences between the wood types were statistically significant (p-value 0.00002 without acid, Fig. 2a and c; p-value 0.00032 with acid Fig. $2 \mathrm{~b}$ and d). The maximum glucose concentration obtained after $48 \mathrm{~h}$ was $3.1 \mathrm{~g} / \mathrm{L}$ (i.e. a yield of $0.14 \mathrm{~g}_{\text {glucose }} / \mathrm{g}_{\text {solids }}$ ) for birch and $1.6 \mathrm{~g} / \mathrm{L}\left(0.076 \mathrm{~g}_{\text {glucose }} / \mathrm{g}_{\text {solids }}\right)$ for spruce.

Additional file 1: Figure S1 shows the effects of each pretreatment variable on the saccharification yield. In general, increasing the concentration of ethanol in OS pretreatment reduced the saccharification yield for birch (p-value 0.0061), but not for spruce. The acid catalyst had a positive effect on the saccharification yield of both OSpretreated birch and spruce. Particle size did not influence the saccharification yield for pretreated birch, but a reduction from $<4$ to $<1 \mathrm{~mm}$ had a positive effect on 

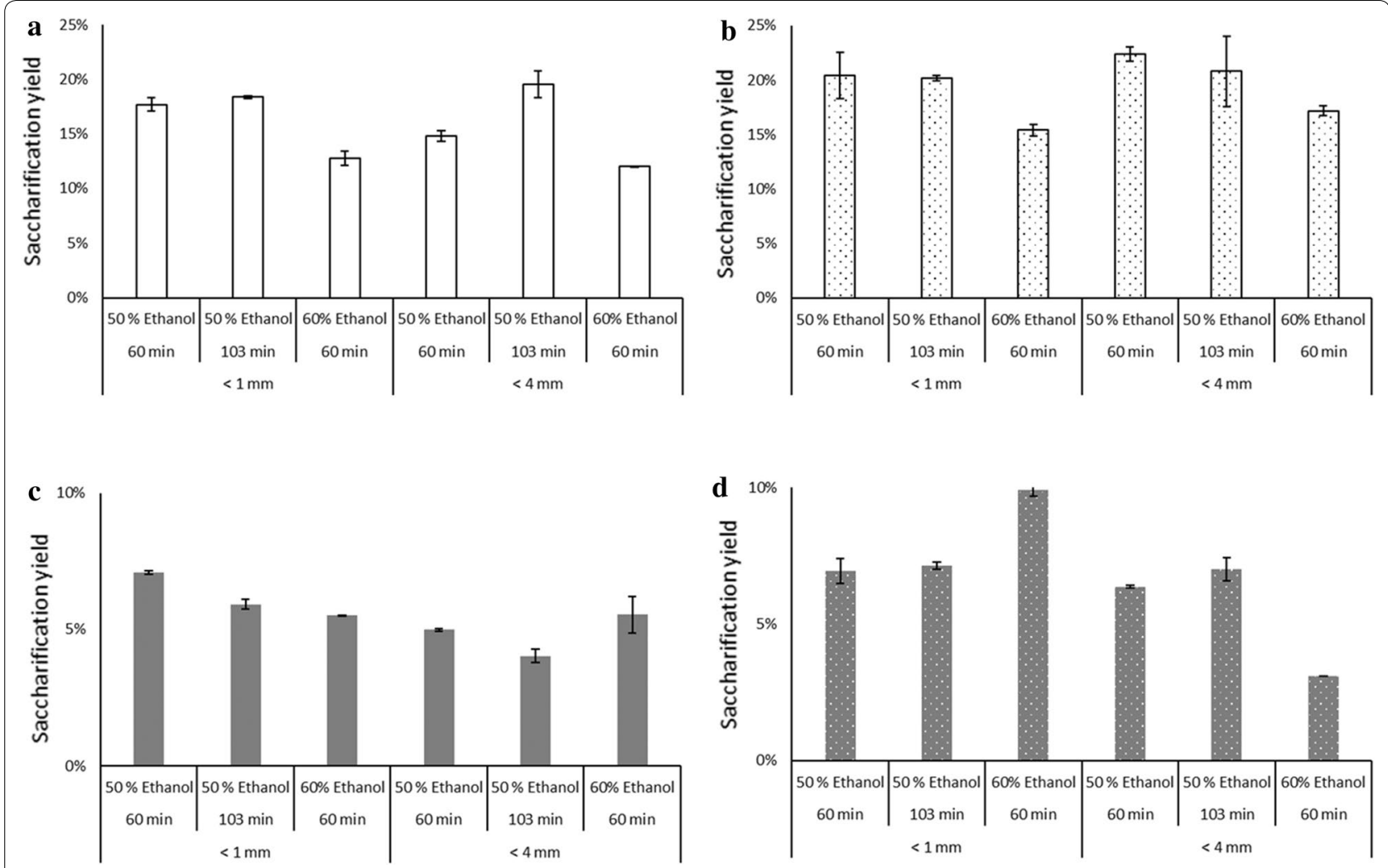

Fig. 2 Saccharification yields of batch OS-pretreated birch and spruce biomass at $2 \%$ solids loading using $20 \mathrm{mg}$ of the enzyme preparation/ $\mathrm{g}_{\text {solidsi }}$ a, b Birch [without and with $1 \% \mathrm{H}_{2} \mathrm{SO}_{4}$ catalyst pretreated with 50 or $60 \%$ ethanol at 60 or $103 \mathrm{~min}$ for a particle size of $<1$ or $<4 \mathrm{~mm}$;]. c, d Spruce [without and with $1 \% \mathrm{H}_{2} \mathrm{SO}_{4}$ catalyst pretreated with 50 or $60 \%$ ethanol at 60 or $103 \mathrm{~min}$ for a particle size of $<1$ or $<4 \mathrm{~mm}$;. See Table 1 for details of the pretreatment conditions. The results shown are the average of two experiments. Columns with dots indicate OS with acid catalyst

pretreated spruce. The pretreatment time did not seem to affect the saccharification yields significantly. An average saccharification yield of $18 \%$ ( $20 \%$ with SE) was obtained with OS-pretreated birch, and 6\% (5\% with SE) with spruce.

\section{Enzyme dosage studies}

The effect of varying the enzyme dosage on the enzymatic saccharification of selected samples of OS-pretreated birch and spruce was also studied. The pretreatment conditions that gave the highest yield in the screening process were employed, i.e. $50 \%$ ethanol, $1 \%$ acid, for birch, and $60 \%$ ethanol and $1 \%$ acid for spruce, both at a particle size of $<1 \mathrm{~mm}$. The results of these studies are shown in Fig. 3a. Doubling the enzyme dosage more than tripled the saccharification yield for pretreated birch, while pretreated spruce exhibited a modest 2.4-fold increase in yield. Almost $100 \%$ saccharification was achieved for birch when applying $150 \mathrm{mg}$ enzyme preparation $/ \mathrm{g}_{\text {sol- }}$ ids whereas the highest saccharification yield obtained for spruce was $70 \%$, when applying $400 \mathrm{mg}$ enzyme preparation $/ \mathrm{g}_{\text {solids. }}$. The highest glucose concentrations achieved were 16 and $8 \mathrm{~g} / \mathrm{L}$ for pretreated birch and spruce, respectively. The saccharification yields from the batch OS-pretreated samples were compared with those from samples pretreated with SE (Fig. 3b). Doubling the enzyme dosage lead to a 2.3-fold increase in saccharification yield for SE-pretreated birch and a 3.2-fold increase for SE-pretreated spruce. The maximum saccharification yields obtained were $91 \%$ for SE-pretreated birch and $66 \%$ for SE-pretreated spruce, when applying $300 \mathrm{mg}$ enzyme preparation $/ g_{\text {solids }}\left(45 \mathrm{FPU} / \mathrm{g}_{\text {solids }}\right.$ ).

\section{Discussion}

As forest-based industries play a vital role in the Swedish economy, we focused on two woody raw materials: birch and spruce. Birch is a hardwood (angiosperm), widespread in the Northern Hemisphere. The lignin content varies between 18 and $25 \%$, and consists of guaiacyl-syringyl units formed by the co-polymerization of coniferyl and sinapyl alcohols. Spruce, a softwood (gymnosperm), has a lignin content of more than $25 \%$, and consists of guaiacyl units with a smaller proportion of unmethoxylated p-hydroxyphenyl units (Campbell and 

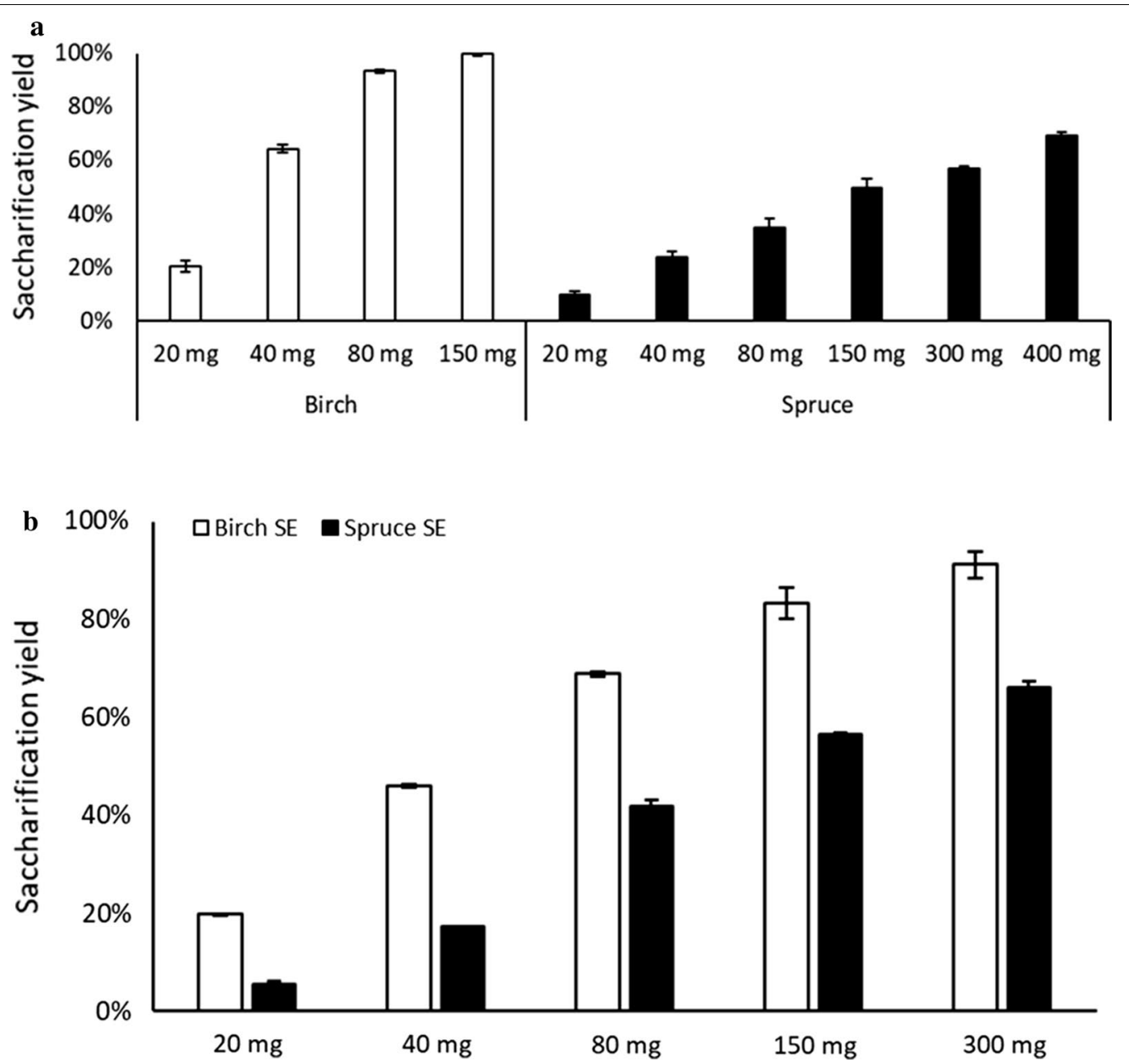

Fig. 3 Results of the enzyme dosage studies on birch and spruce biomass at 2\% w/v loadings pretreated with a OS and $\mathbf{b}$ SE [Composition of SE birch samples and the saccharification yields taken from Matsakas et al. (2018)]

Sederoff 1996). It is well documented that OS pretreatment reduces the crystallinity of cellulose and enriches the cellulose fraction in the biomass through efficient delignification (Zhang et al. 2009; Zhao et al. 2009; Ju et al. 2014). High methane titers have been obtained by anaerobic digestion of OS-pretreated biomass (Matsakas et al. 2017). The superior quality of OS lignin, i.e. lower molecular weight and increased phenolic $\mathrm{OH}$ content (Nitsos et al. 2016), offers valorization through the production of biochemicals or as green phenol substitutes (Benar et al. 1999; Ruiz-Dueñas and Martínez 2009).

High saccharification yield of pretreated biomass is a prerequisite for subsequent bioconversion processes. Lignin present in the pretreated biomass is known to interfere with the enzymatic hydrolysis by forming a lignin-carbohydrate complex (Berlin et al. 2006). Nitsos and co-workers (2016) showed that their OS pretreatment resulted in a lignin removal efficiency of 69 and
$62 \%$ for birch and spruce respectively. In the present work, we extended the work of Nitsos and co-workers to correlate the pretreatment variables with the saccharification yield. OS pretreatment enhanced the enzymatic digestibility of birch more efficiently than spruce; 95\% saccharification was achieved with birch with $80 \mathrm{mg}$ (12 FPU) enzyme preparation/g $/ \mathrm{g}_{\text {solids, }}$, while $70 \%$ was attained in spruce with $400 \mathrm{mg}$ enzyme preparation $/ g_{\text {solids }}(60 \mathrm{FPU})$ (Fig. 3a). To compare, Obama and co-workers (Obama et al. 2012) used OS pretreatment of miscanthus, at a temperature of $170{ }^{\circ} \mathrm{C}$, for 60 min using $80 \%(\mathrm{v} / \mathrm{v})$ ethanol $+1 \%(\mathrm{w} / \mathrm{w}) \mathrm{H}_{2} \mathrm{SO}_{4}$ and report a saccharification yield of $\sim 55 \%$ at 40 IFPU of Celluclast ${ }^{\circledR} 1.5 \mathrm{~L} / \mathrm{g}$ of cellulose at a solids loading of $2 \%$ $(\mathrm{w} / \mathrm{v})$. It is likely that the high ethanol concentration they have used employed in the pretreatment prevented the complete hydrolysis of the biomass (compared to $95 \%$ for birch at $12 \mathrm{FPU}$ and $56 \%$ for spruce at 45 
FPU at 2\% solids loading in our study). Smit and Huijgen (2017) used acetone-water $(50 \% \mathrm{w} / \mathrm{w})$ containing $40 \mathrm{mM} \mathrm{H}_{2} \mathrm{SO}_{4}$ at $140{ }^{\circ} \mathrm{C}$ and $120 \mathrm{~min}$ and report a saccharification yield of 78 and $16 \%$ for birch and spruce respectively at an enzyme loading of $10 \mathrm{FPU} / \mathrm{g}_{\text {solids }}$ (Accellerase TRIO) at 10\% (w/v) solids loading (compared to a saccharification yield of 95 and 34\% for birch and spruce at $12 \mathrm{FPU} / \mathrm{g}_{\text {solids }}$ at $2 \%$ solids loading in our study). As the saccharification yield is affected by the OS pretreatment process conditions, the type of solvent used in the OS, the type of enzyme cocktail used, as well as the consistency of solids during the hydrolysis process in small scale, it is harder to make a direct comparison with values reported in the literature.

As the hemicellulose fraction contains higher levels of glucuronoxylan (birch) or galactoglucomannan (spruce), the release of sugars of hemicellulosic origin was observed in birch and spruce respectively, during the saccharification process in samples not treated with the acid catalyst. This is an indication that the solubilization of hemicellulose was incomplete, and that treatment with an acid catalyst is needed for the efficient removal of hemicellulose. Thus, acid catalyst results in increased hemicellulose solubilization, decreased lignin - by cleaving the aryl-ether bonds (Sturgeon et al. 2014), resulting in increased cellulose content and saccharification yields. A decrease in saccharification yield observed with increasing amounts of ethanol indicates that there is an optimal ethanol concentration that offers the highest saccharification yield. Contrarily, low ethanol concentrations result in increased water activity, which creates more acidic conditions and promotes the cleavage of the $\alpha$ and $\beta$ linkages in lignin (McDonough 1993). The difference in the saccharification yields seen in spruce and birch is due to differences in the lignin chemistry (different composition) and the non-productive interaction between the enzymes and lignin (Berlin et al. 2006). Few data are available on the effect of pretreatment time on the saccharification yield, but there is evidence that shorter pretreatment is favorable as the carbohydrate solubilization was not significantly increased when longer times were employed (Nitsos et al. 2016). In spruce, without the acid catalyst, increasing the duration of pretreatment decreases the saccharification yield, but the effect is reversed in the presence of the acid catalyst-increased saccharification yield with increased pretreatment time (Fig. 2c, d). Prolonged pretreatment might result in the formation of pseudo-lignin that could lead to an overestimation of lignin content and affect the accessibility of enzymes during enzymatic hydrolysis (Kumar et al. 2013). A retro-techno-economic analysis of the pretreatment, hydrolysis and fermentation process would be able to ascertain the process boundaries for economic feasibility (Longati et al. 2018) for further research and development.

In the final part of this study, OS pretreatment was compared with the traditional SE. Although the saccharification yield was at a comparable level for both SE and OS at the lower enzyme dosage ( $20 \mathrm{mg}$ of enzyme preparation $\left./ \mathrm{g}_{\text {solids }}\right)$ for birch, significant differences could be observed at $80 \mathrm{mg}$ of enzyme preparation $/ \mathrm{g}_{\text {solids }}(69 \%$ for SE vs. 93\% with OS) as seen in Fig. 3a and b. In the case of spruce, the differences were less prominent. However, due to the differences in cellulose content between OSand SE-pretreated woody biomass, the yield of glucose was higher following OS than SE (0.74 vs. 0.53 , and 0.37 vs. $0.24 \mathrm{~g}_{\text {glucose }} / \mathrm{g}_{\text {solids }}$, with $150 \mathrm{mg}$ enzyme preparation/ $\mathrm{g}_{\text {solids }}$ for birch and spruce, respectively). Thus, more glucose can be released per gram of OS-pretreated birch biomass upon hydrolysis. For example, with $20 \mathrm{wt} \%$ of OS-pretreated birch, the amount of glucose released would be $\sim 150 \mathrm{~g} / \mathrm{L}$ (compared to $\sim 106 \mathrm{~g} / \mathrm{L}$ with SE). Upon fermentation by yeast, this would give a theoretical ethanol yield of $\sim 77 \mathrm{~g} / \mathrm{L}(54 \mathrm{~g} / \mathrm{L}$ with SE), demonstrating the potential for OS pretreatment over SE. Even though the cellulose conversion yields are similar between OS and SE, OS has the added advantage that the hemicellulose and lignin fraction can be collected as pure streams and could be utilized to produce other high-added value products, through chemical and biochemical routes.

In the present study, we used $2 \% \mathrm{w} / \mathrm{v}$ dry matter in the hydrolysis experiments, hence the theoretical amount of glucose that could be released is $\sim 22 \mathrm{~g} / \mathrm{L}$. To achieve economically feasible titers of ethanol in a fermentation process $(>100 \mathrm{~g} / \mathrm{L})$, it is necessary to use high dry matter concentrations. As the aim of this study was to screen the pretreatment conditions, a low enzyme dosage and a low dry matter loading of $2 \% \mathrm{w} / \mathrm{v}$ were used as these are easier to handle and mix, leading to less experimental variation. Based on the maximum glucose concentration of $16 \mathrm{~g} / \mathrm{L}$ (equivalent to $0.8 \mathrm{~g}_{\text {glucose }} / \mathrm{g}_{\text {solids }}$ ) observed after the hydrolysis of OS-pretreated birch, we suggest that similar hydrolytic yields could be attained at higher consistency using a free-fall mixer (Matsakas and Christakopoulos 2013; Katsimpouras et al. 2017b). However, spruce appears to be more recalcitrant, as the highest glucose concentration observed was $13 \mathrm{~g} / \mathrm{L}$ (equivalent to $\left.0.52 \mathrm{~g}_{\text {glucose }} / \mathrm{g}_{\text {solids }}\right)$, and a saccharification yield of $70 \%$ at an enzyme dosage of $400 \mathrm{mg}$ enzyme preparation $/ \mathrm{g}_{\text {solids }}$.

One of the main drawbacks of the current batch OS process is the downtime between the runs. Thus, we are currently developing a continuous mode process that combines batch OS with explosive decompression of the biomass, which we hope will decrease the residence time and open the cellulose structure to improve enzyme access (Seidel et al. 2017). Life cycle assessment 
studies comparing the various pretreatment processes (Prasad et al. 2016) have shown that OS has no significant negative impact on the environment compared to $\mathrm{SE}$, although the $\mathrm{CO}_{2}$ emission is higher due to the need to produce ethanol for the OS process (the ethanol can be distilled and recirculated, greatly reducing the net emission). Thus, OS appears to offer a promising method of pretreatment as the hydrolysate obtained is free from inhibitors, while simultaneously offering valorization of the hemicellulose and lignin stream. Retrofitting existing first-generation ethanol plants with the OS process to supply the sugar stream may help second-generation ethanol to become a commercial reality.

\section{Additional file}

Additional file 1: Figure S1. Effects of the individual pretreatment variables on the saccharification yields. Ethanol concentration (50 or 60\%), size of the wood chips employed $(<1 \mathrm{~mm}$ or $<4 \mathrm{~mm})$, the presence or the absence of an acid catalyst $\left(\mathrm{H}_{2} \mathrm{SO}_{4}\right)(0$ or $1 \%)$, and the duration of pretreatment (60 min or $103 \mathrm{~min}$ ). Open symbols: birch; filled symbols: spruce. Table S1. Hydrolytic yields reported in the literature using Cellic CTec2 for various pretreatment methods.

\section{Abbreviations}

SE: steam explosion; OS: organosolv.

\section{Authors' contributions}

VR performed the hydrolysis experiments; LM and CN carried out the SE and OS pretreatment; VR wrote the manuscript and all authors contributed to the data analysis and commented on the manuscript. All authors read and approved the final manuscript.

\section{Author details \\ ${ }^{1}$ Industrial Biotechnology Division, Department of Biology and Biological Engineering, Chalmers University of Technology, Kemivägen 10, 41296 Goth- enburg, Sweden. ${ }^{2}$ Biochemical Process Engineering, Chemical Engineering Division, Department of Civil, Environmental and Natural Resources Engineer- ing, Luleå University of Technology, 97187 Luleå, Sweden. ${ }^{3}$ Department of Molecular Biology and Biotechnology, The University of Sheffield, Firth Court, Western Bank, Sheffield S10 2TN, UK.}

\section{Acknowledgements}

The authors would also like to thank Sveaskog, Sweden, for providing the birch and spruce chips that were used in this study. PC, UR and LM would like to thank Bio4Energy, a Swedish strategic research environment, and the Kempe Foundation for financial support.

\section{Competing interests}

The authors declare that they have no competing interests.

\section{Consent for publication \\ Not applicable.}

Ethics approval and consent to participate

Not applicable.

\section{Funding}

This work was funded by the Swedish Energy Agency as part of the SolvFuels project (SWEDISH ENERGY AGENCY project SOLVEFUELS: 2015-1096).

\section{Publisher's Note}

Springer Nature remains neutral with regard to jurisdictional claims in published maps and institutional affiliations.

Received: 23 April 2018 Accepted: 5 July 2018

Published online: 10 July 2018

\section{References}

Benar P, Gonçalves AR, Mandelli D, Schuchardt U (1999) Eucalyptus organosolv lignins: study of the hydroxymethylation and use in resols. Bioresour Technol 68:11-16. https://doi.org/10.1016/S0960-8524(98)00076-5

Berlin A, Balakshin M, Gilkes N, Kadla J, Maximenko V, Kubo S, Saddler J (2006) Inhibition of cellulase, xylanase and $\beta$-glucosidase activities by softwood lignin preparations. J Biotechnol 125:198-209. https://doi.org/10.1016/j. jbiotec.2006.02.021

Brosse N, Hussin MH, Rahim AA (2017) Organosolv processes. In: Advances in biochemical engineering/biotechnology. Springer, Berlin, Heidelberg

Campbell MM, Sederoff RR (1996) Variation in lignin content and composition. Plant Physiol 1996:3-13. https://doi.org/10.1104/pp.110.1.3

Guragain YN, Bastola KP, Madl RL, Vadlani PV (2016) Novel biomass pretreatment using alkaline organic solvents: a green approach for biomass fractionation and 2,3-butanediol production. BioEnergy Res 9:643-655. https://doi.org/10.1007/s12155-015-9706-y

Houghton JT (2009) Global warming: the complete briefing. Cambridge University Press, Cambridge

IPCC (2014) Climate change 2014: impacts, adaptation, and vulnerability. http://www.ipcc.ch/report/ar5/wg2/. Accessed 12 Apr 2014

Johansson A, Aaltonen O, Ylinen P (1987) Organosolv pulping - methods and pulp properties. Biomass 13:45-65. https://doi.org/10.1016/01444565(87)90071-0

Ju X, Bowden M, Engelhard M, Zhang X (2014) Investigating commercial cellulase performances toward specific biomass recalcitrance factors using reference substrates. Appl Microbiol Biotechnol 98:4409-4420. https:// doi.org/10.1007/s00253-013-5450-4

Katsimpouras C, Kalogiannis KG, Kalogianni A, Lappas AA, Topakas E (2017a) Production of high concentrated cellulosic ethanol by acetone/water oxidized pretreated beech wood. Biotechnol Biofuels 10:54. https://doi. org/10.1186/s13068-017-0737-9

Katsimpouras C, Zacharopoulou M, Matsakas L, Rova U, Christakopoulos P, Topakas E (2017b) Sequential high gravity ethanol fermentation and anaerobic digestion of steam explosion and organosolv pretreated corn stover. Bioresour Technol 244:1129-1136. https://doi.org/10.1016/j.biort ech.2017.08.112

Kleinert T, v. Tayenthal K (1931) Über neuere Versuche zur Trennung von CelIulose und Inkrusten verschiedener Hölzer. Zeitschrift für Angew Chemie 44:788-791. https://doi.org/10.1002/ange.19310443903

Kluts IN, Brinkman MLJ, de Jong SA, Junginger HM (2017) Biomass resources: agriculture. Adv Biochem Eng Biotechnol. https://doi. org/10.1007/10_2016_66

Kumar R, Hu F, Sannigrahi P, Jung S, Ragauskas AJ, Wyman CE (2013) Carbohydrate derived-pseudo-lignin can retard cellulose biological conversion. Biotechnol Bioeng 110(3):737-753. https://doi.org/10.1002/bit.24744

Lange L (2017) Fungal enzymes and yeasts for conversion of plant biomass to bioenergy and high-value products. Microbiol Spectr. https://doi. org/10.1128/microbiolspec.FUNK-0007-2016

Limayem A, Ricke SC (2012) Lignocellulosic biomass for bioethanol production: current perspectives, potential issues and future prospects. Prog Energy Combust Sci 38:449-467. https://doi.org/10.1016/j. pecs.2012.03.002

Longati AA, Lino ARA, Giordano RC, Furlan FF, Cruz AJG (2018) Defining research \& development process targets through retro-techno-economic analysis: the sugarcane biorefinery case. Bioresour Technol 26(263):1-9. https://doi.org/10.1016/.j.biortech.2018.04.102

Matsakas L, Christakopoulos P (2013) Fermentation of liquefacted hydrothermally pretreated sweet sorghum bagasse to ethanol at high-solids content. Bioresour Technol 127:202-208. https://doi.org/10.1016/J.BIORT ECH.2012.09.107 
Matsakas L, Nitsos C, Vörös D, Rova U, Christakopoulos P (2017) High-titer methane from organosolv-pretreated spruce and birch. Energies 10:263. https://doi.org/10.3390/en10030263

Matsakas L, Nitsos C, Raghavendran V, Yakimenko O, Persson G, Olsson E, Rova U, Olsson L, Christakopoulos P (2018) A novel hybrid organosolv: steam explosion method for the efficient fractionation and pretreatment of birch biomass. Biotechnol Biofuels 8(11):160. https://doi.org/10.1186/ s13068-018-1163-3

McCann MC, Carpita NC (2015) Biomass recalcitrance: a multi-scale, multifactor, and conversion-specific property. J Exp Bot 66:4109-4118. https:// doi.org/10.1093/jxb/erv267

McDonough TJ (1993) The chemistry of organosolv delignification. Tappi J 76:186-193

Mosier N, Wyman C, Dale B, Elander R, Lee YY, Holtzapple M, Ladisch M (2005) Features of promising technologies for pretreatment of lignocellulosic biomass. Bioresour Technol 96:673-686. https://doi.org/10.1016/j.biort ech.2004.06.025

Nguyen TY, Cai CM, Kumar R, Wyman CE (2015) Co-solvent pretreatment reduces costly enzyme requirements for high sugar and ethanol yields from lignocellulosic biomass. ChemSusChem. https://doi.org/10.1002/ cssc.201403045

Nitsos C, Stoklosa R, Karnaouri A, Vörös D, Lange H, Hodge D, Crestini C, Rova U, Christakopoulos P (2016) Isolation and characterization of organosolv and alkaline lignins from hardwood and softwood biomass. ACS Sustain Chem Eng 4:5181-5193. https://doi.org/10.1021/acssuschemeng.6b012 05

Obama P, Ricochon G, Muniglia L, Brosse N (2012) Combination of enzymatic hydrolysis and ethanol organosolv pretreatments: effect on lignin structures, delignification yields and cellulose-to-glucose conversion. Bioresour Technol 2012(112):156-163. https://doi.org/10.1016/j.biort ech.2012.02.080

Pan X, Arato C, Gilkes N, Gregg D, Mabee W, Pye K, Xiao Z, Zhang X, Saddler $J$ (2005) Biorefining of softwoods using ethanol organosolv pulping: preliminary evaluation of process streams for manufacture of fuel-grade ethanol and co-products. Biotechnol Bioeng 90:473-481. https://doi. org/10.1002/bit.20453

Perlack RD, Stokes BJ (Leads) (2011) US billion-ton update: biomass supply for a bioenergy and bioproducts industry. ORNL/TM-2011/224

Piotrowski JS, Zhang Y, Bates DM, Keating DH, Sato TK, Ong IM, Landick R (2014) Death by a thousand cuts: the challenges and diverse landscape of lignocellulosic hydrolysate inhibitors. Front Microbiol 5:90. https://doi. org/10.3389/fmicb.2014.00090

Piotrowski JS, Okada H, Lu F, Li SC, Hinchman L, Ranjan A, Smith DL, Higbee AJ, Ulbrich A, Coon JJ, Deshpande R, Bukhman YV, Mcllwain S, Ong IM, Myers CL, Boone C, Landick R, Ralph J, Kabbage M, Ohya Y (2015) Plant-derived antifungal agent poacic acid targets $\beta$-1,3-glucan. Proc Natl Acad Sci 112:201410400. https://doi.org/10.1073/pnas.1410400112
Prasad A, Sotenko M, Blenkinsopp T, Coles SR (2016) Life cycle assessment of lignocellulosic biomass pretreatment methods in biofuel production. Int J Life Cycle Assess 21:44-50. https://doi.org/10.1007/s11367-015-0985-5

Robertson GP, Hamilton SK, Barham BL, Dale BE, Izaurralde RC, Jackson RD, Landis DA, Swinton SM, Thelen KD, Tiedje JM (2017) Cellulosic biofuel contributions to a sustainable energy future: choices and outcomes. Science 356:eaal2324. https://doi.org/10.1126/science.aal2324

Ruiz-Dueñas FJ, Martínez ÁT (2009) Microbial degradation of lignin: how a bulky recalcitrant polymer is efficiently recycled in nature and how we can take advantage of this. Microb Biotechnol 2:164-177. https://doi.org/ 10.1111/j.1751-7915.2008.00078.x

Sannigrahi P, Ragauskas AJ (2013) Fundamentals of biomass pretreatment by fractionation. In: Wyman CE (ed) Aqueous pretreatment of plant biomass for biological and chemical conversion to fuels and chemicals. John Wiley \& Sons Ltd, pp 201-222

Seidel C-M, Pielhop T, Studer MH, Rudolf von Rohr P (2017) The influence of the explosive decompression in steam-explosion pretreatment on the enzymatic digestibility of different biomasses. Faraday Discuss 202:269-280. https://doi.org/10.1039/c7fd00066a

Smil V (2004) World history and energy. Encycl Energy 6:549-561

Smit A, Huijgen W (2017) Effective fractionation of lignocellulose in herbaceous biomass and hardwood using a mild acetone organosolv process. Green Chem 19:5505-5514. https://doi.org/10.1039/C7GC02379K

Sturgeon MR, Kim S, Lawrence K, Paton RS, Chmely SC, Nimlos M, Foust TD, Beckham GT (2014) A mechanistic investigation of acid-catalyzed cleavage of aryl-ether linkages: implications for lignin depolymerization in acidic environments. ACS Sustain Chem Eng 2:472-85

Tan H-T, Corbin KR, Fincher GB (2016) Emerging technologies for the production of renewable liquid transport fuels from biomass sources enriched in plant cell walls. Front Plant Sci 7:1854. https://doi.org/10.3389/ fpls.2016.01854

The World Bank (2014) World development indicators. https://openknowle dge.worldbank.org/bitstream/handle/10986/18237/9781464801631. pdf?sequence $=1$. Accessed 7 Nov 2017

Wang R, Koppram R, Olsson L, Franzén CJ (2014) Kinetic modeling of multi-feed simultaneous saccharification and co-fermentation of pretreated birch to ethanol. Bioresour Technol 172:303-311. https://doi. org/10.1016/j.biortech.2014.09.028

Ximenes E, Kim Y, Mosier N, Dien B, Ladisch M (2011) Deactivation of cellulases by phenols. Enzyme Microb Technol 48:54-60. https://doi.org/10.1016/j. enzmictec.2010.09.006

Zhang X, Oin W, Paice MG, Saddler JN (2009) High consistency enzymatic hydrolysis of hardwood substrates. Bioresour Technol 100:5890-5897. https://doi.org/10.1016/j.biortech.2009.06.082

Zhao X, Cheng K, Liu D (2009) Organosolv pretreatment of lignocellulosic biomass for enzymatic hydrolysis. Appl Microbiol Biotechnol 82:815-827. https://doi.org/10.1007/s00253-009-1883-1

\section{Submit your manuscript to a SpringerOpen ${ }^{\circ}$ journal and benefit from:}

- Convenient online submission

- Rigorous peer review

- Open access: articles freely available online

- High visibility within the field

Retaining the copyright to your article

Submit your next manuscript at springeropen.com 